\title{
Sedimentation and Mutations of Armenian Knowledge about the Genocide
}

Armenians are, in Max Weber's terms, an ethno-religious carrier group. Many ancestors of today's Armenians are survivors of the mass violence of 1915 and subsequent years. These ancestors suffered through great cruelties and experienced grave losses, and later generations of Armenians are receptive to the accumulated genocide knowledge documented in the first two chapters. While those chapters showed great fluidity of knowledge in its early production and intergenerational transmission, I now focus on Armenian repertoires of genocide knowledge in its sedimented form-relatively stable, but subject to modifications.

Armenians, of course, are not a monolithic group. Some three million live in Armenia, long a Soviet Republic but since 1991 an independent country. Millions of others live in the diaspora, many in France and the United States, where they wage mnemonic struggles against adversaries (see chapters 7 and 8). Armenians are divided further by political convictions, by degrees of involvement in religious life, by levels of participation in Armenian organizations, and by age cohorts and generations. While keeping these distinctions in mind, I first focus on knowledge in Armenia about the mass violence of 1915, and then turn to the diaspora.

\section{GENOCIDE KNOWLEDGE IN ARMENIA}

On a hill named Tsitsernakaberd, overlooking the one-million-inhabitant city of Yerevan, capital of the Republic of Armenia, is a memorial complex "dedicated to the memory of 1.5 million Armenians" who perished in the genocide. The complex "consists of three main buildings: the Memorial Wall, the Sanctuary of Eternity (Memorial Hall \& Eternal Flame) and the Memorial Column 'The Reborn Armenia." 
It signifies the memory of the violence the Armenian people endured. The message is explicated on the website of the memorial complex, from which I took the above quotations. ${ }^{1}$ It is worth quoting from this text in detail:

Tsitsernakaberd Memorial Complex in Yerevan is dedicated to the memory of the 1.5 million Armenians who perished in the first genocide of the 20th century, at the hands of the Turkish government. Completed in 1967, the Genocide Monument has since become a pilgrimage site and an integral part of Yerevan's architecture. Set high on a hill, dominating the landscape, it is in perfect harmony with its surroundings. The austere outlines convey the spirit of the nation that survived a ruthless campaign of extermination....

Before reaching the central part of the monument, visitors first observe a 100-meter long basalt Memorial Wall with the names of cities engraved in stone. The names also include the Armenian populations that were massacred by Turks during the Genocide campaign. Since 1996, the last portion of the Memorial Wall houses glass casings that contain soil taken from the tombs of political and intellectual figures who raised their protest against the Genocide committed against the Armenians by the Turks. Among them are Armin Wegner, Hedvig Bull, Henry Morgenthau, Franz Werfel, Yohannes Lepsius, James Bryce, Anatole France, Jakomo Gorini, Benedict XV, Fritioff Nansen, Fayez El Husseyn.

As part of the Monument, an arrow-shaped stele of granite, 44 meters high, reaches to the sky, symbolizing the survival and spiritual rebirth of the Armenian people. Partly split vertically by a deep crevice, this tower symbolizes the tragic and violent dispersion of the Armenian people, and at the same time, expresses the unity of the Armenian people.

At the center of the Monument stands the circular Memorial Sanctuary. Its unroofed walls consist of twelve, tall, inward-leaning basalt slabs forming a circle. The shape of these walls simulates traditional Armenian khatchkars, which are stone slabs with large carved crosses at the center. These slabs also suggest figures in mourning. The level of the floor of the Genocide Monument is set at one and a half meters lower than the walkway. At its center, there is an eternal flame, which memorializes all the victims of the Genocide. The steps leading down to the eternal flame are steep, thus requiring visitors to bow their heads reverently as they descend.

The symbol-rich buildings of the Tsitsernakaberd Memorial Complex represent what collective memory scholars call structural memory, something carved in stone, a monument that endures. Yet the meaning attributed to monuments is subject to variation across social groups and time. The above interpretation is provided by the Armenian Genocide Museum-Institute, part of the National Academy of Sciences of the Republic of Armenia. I conceive of the Museum-Institute as a macro-level actor seeking to offer a binding and universal interpretation of the mass violence committed against the Armenians. In doing so, it does what memory entrepreneurs commonly do: it answers "questions to which a successful process of collective representation must provide compelling answers: A. The nature of the pain . . B. The nature of the victim . . C. Relation of the trauma 
victim to the wider audience ... [and] D. Attribution of Responsibility" (Alexander 2004:12-14). Below, I address each of these in turn.

The nature of the pain is captured, in the long passage quoted above, in the words perished, extermination, tragic and violent dispersion, and the repeated use of the term genocide, as in "first genocide of the 2oth century," "genocide campaign," and two more times just "genocide." The word first gives the events of 1915 historical primacy over the sequence of subsequent genocides, the second of which is the Holocaust. Such primacy must be important to the authors, all the more so as it omits the genocide committed by the German military against the Herero and Namaqua in 1904 to 1908 in Namibia, then German South West Africa. It is unlikely that the authors are not mindful of this event, especially given the historical proximity and the similarity of the main method of extermination: driving the population into the desert so they would painfully perish.

The text also determines the nature of the victims: "1.5 million Armenians," "Armenian populations," and "the Armenian people." The categorization is already implicit in the term genocide, defined by the Genocide Convention as acts directed against a "national, ethnical, racial or religious group" with the intent to destroy that group, "in whole or in part." The authors writing for the Museum-Institute also attribute responsibility, defining the perpetrator as "the Turkish government," "Turks," and "the Turks." The text does not speak to its authors' relationship to a wider audience. Yet the annual memorial events of April 24, discussed in detail in chapter 6, do provide an answer. On these occasions, the president of Armenia and the head, or Catholicos, of the Armenian Apostolic Church lead members of the cabinet, a procession of celebrities, diplomats, and scholars from around the globe; and tens of thousands of Armenians into the memorial. Through this representation, and the invitations that precede it, the rituals reach a large international audience.

The text describing the Tsitsernakaberd Memorial Complex provides a distilled narrative of the violence against the Ottoman Armenians during World War I. Mnemonic entrepreneurs-motivated and in a privileged institutional position, suited to reach a wide audience-classify the suffering, the victims, and the perpetrators, and establish a relationship between victims and a world audience. The memorial and rituals provide the tools. Local audiences are likely to subscribe to the narrative, given three conditions the current context fulfills. The first is uncertainty, generated by continuing Turkish challenges to the narrative, an unstable state history, and a neighborhood of potential aggressors. The history of Armenian acts of perpetration -incomparably more limited, to be sure, than those the Armenian people endured-may also play into this uncertainty. The second condition is the sedimentation of knowledge through decades of interpersonal communication. The third is the relative lack of communication between the antagonists.

In short, the memorial site of Tsitsernakaberd hill, supplemented by the text on the website of the Museum-Institute, provides us with a condensed narrative of the Armenian genocide. Shared by Armenian communities around the globe, it 
is relatively stable, supported by the confluence of knowledge diffused in informal social networks over many decades. Yet this narrative is not the natural outcome of the events unfolding in the Ottoman Empire. Human agency intervened, and knowledge entrepreneurs played a prominent role, leading up to the contemporary understanding.

A series of articles by Armenian scholar Harutyun Marutyan (2007, 2010, 2014a, 2014b) sheds light on the process that cumulatively formed the dominant narrative. Marutyan distinguishes between three major stages: the silence of the 1920s, the definition of victim status resulting in the establishment of the memorial in 1967, and the emergence of a new Armenian identity beginning in 1988. His account provides us with insights into the stability and the flexibility of Armenian genocide knowledge, and into the social forces that contribute to both.

\section{Repression and Quiet Reminders: Postwar Memories}

The introduction to this book provides a brief overview of the conquest of the Armenian people by the Ottoman Turks and the 1923 division of the short-lived post-World War I Armenian state between the Soviet Union and Turkey. The Soviet-occupied part was initially incorporated into a Transcaucasian Socialist Republic. Conditions for the cultivation of an Armenian public national memory in the new Soviet Union were poor, and the new multinational country fought, with an iron fist, any nationalist movements. Marutyan (2010) attributes the withering of collective memories of the Armenian genocide in the early years of Soviet domination to this antinational context. Massive displacements of ethnic populations and the internment of Soviet-Armenian intellectuals in the Gulags, especially during Stalin's Great Purge of 1938, further contributed to discontinuities of collective memories (Mouradian 2003; Werth 1998; Polian 2004). Note that this was the second destruction of Armenian intellectuals within less than a quarter century, occurring just twenty-three years after the April 1915 arrests, deportations, and killings of leading Armenians in the Ottoman Empire. The associated memory loss must have been devastating.

At the level of informal social life, Armenian genocide survivors nevertheless cautiously cultivated knowledge about the horrors they and their ancestors had experienced, even if that cultivation was perforated by the kinds of silencing we encountered in chapter 1. Cultivation of knowledge even found written expression: "The national tragedy first appeared in Soviet Armenian literature in the form of literary descriptions of childhood reminiscences. Writers who survived the atrocities of genocide, and lost their motherland, recalled their childhood years and places dear to them, [yet] without actually speaking about the fact of genocide" (Marutyan 2010:24-25). There had thus emerged a knowledge repertoire, a form of cultural capital-tenuous as it may have been - that enabled Armenians to seize the opportunity for public articulation at the moment of de-Stalinization, initiated by the new party secretary, Nikita Khrushchev, and articulated famously in his speech to the Twentieth Congress of the Soviet Communist Party in 1956. Remember 
also that the international community had established the Genocide Convention eight years earlier. The moment had come to move beyond the vocabulary of "Metz Yeghern" (the Great Crime) that Armenians had used for the mass destruction of their people. The time was right to claim the term genocide.

\section{Approaching the Fiftieth Anniversary: Epistemic Shifts of the 1960s}

The decade following the thaw of the immediate post-Stalinist moment witnessed a rapid expansion of Soviet-Armenian literature. A series of political events helped as it brought the memory of the genocide into public view, albeit still cautiously. In December 1964, the first secretary of the Central Committee of the Armenian Communist Party, Yakov Zarobyan, wrote to the Central Committee of the Communist Party of the Soviet Union (CPSU) with regard to the memory of the Armenian past (Marutyan 2014b). Zarobyan pointed at the prominent role of nationalist forces in the diaspora for the commemoration of Armenian history and noted that "Soviet Armenia does nothing to commemorate the anniversaries of mass killings of Armenians" (quoted in Marutyan 2014b:65). He depicted this omission as dangerous in light of the fact that "our country neglects the memory of hundreds of thousands of our compatriots, thus actually exonerating the policy of genocide" (2014b:65). He concluded: "We think it appropriate to commemorate the 5oth anniversary of the date in the light of the absolute victory of the CPSU Leninist national policy, to signify the great achievements of the reborn Armenian people in the spheres of economy, culture and science" (2014b:65).

The party secretary was mindful of Soviet interests in maintaining constructive relations with Turkey. He stressed that the Armenian tragedy could be commemorated in universalistic terms, without mentioning Turkey's role, in order to move the events from a "level of a solely Armenian tragedy to the level of world history" (Marutyan 2014b:65). The first secretary's letter thus showed great sensitivity to ideological concerns of the Soviet leadership, while simultaneously raising the idea of a memorial. Its author proved himself a skilled and influential knowledge entrepreneur in a sensitive context.

Importantly, mass demonstrations in Yerevan in April 1965, on the fiftieth anniversary of the genocide, followed the initiative by the Armenian communist leadership. Slogans on posters and banners reflected a sense of national renaissance, proclaiming, for example, "Compensate [for] Our Lands" or, with an image of Mount Ararat, Armenia's sacred mountain (on Turkish territory), in the background, "Give a Just Solution to the Armenian Cause" (Marutyan 2010:26).

The skilled moves by the Armenian leadership in combination with these popular demonstrations convinced the government in faraway Moscow that it would be wise to allow for the establishment of a memorial. A competition was held, and construction of the winning design was completed in 1967. It differed substantially from that of monuments in the style of Soviet Socialist Realism, further supporting a sense of Armenian cultural autonomy within the Soviet Union (see figure 3). 


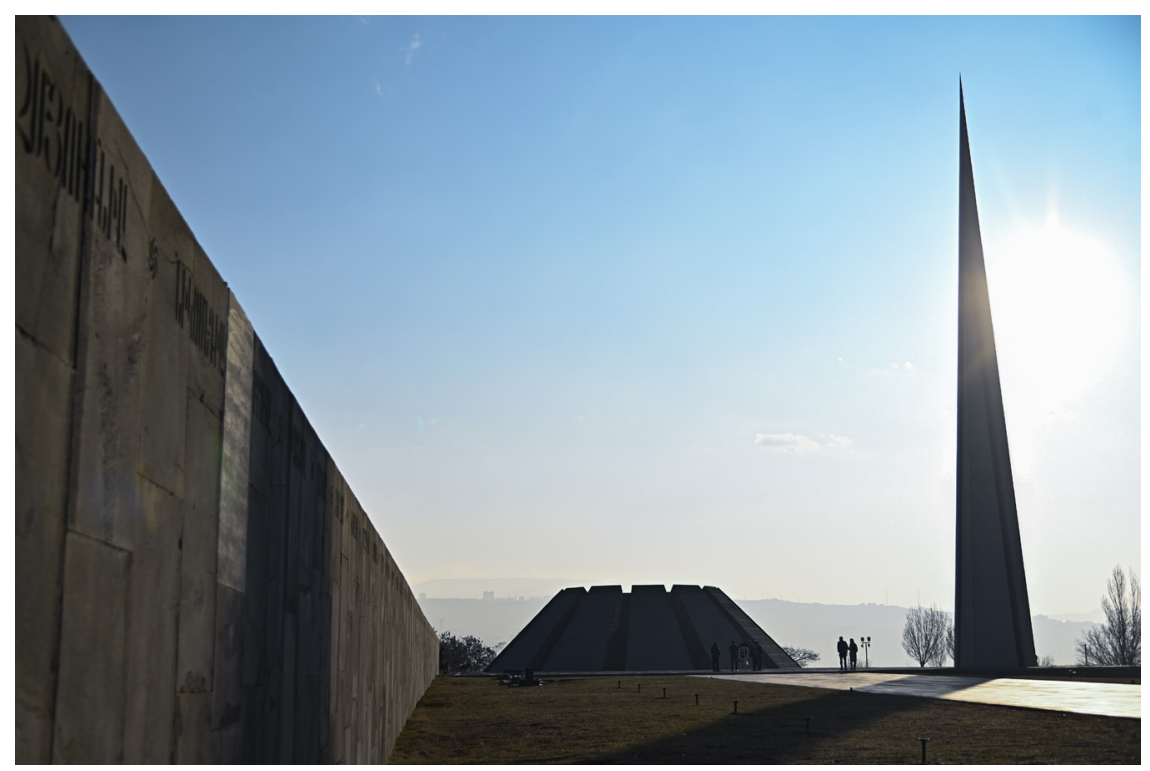

FIGURE 3. Tsitsernakaberd Memorial Complex, Yerevan. Photo courtesy of Ministry of Foreign Affairs, Republic of Armenia.

The Armenian public started flocking to the memorial from the beginning, and in 1975, eight years after its construction, the Soviet Armenian leadership began official visits, laying wreaths on April 24, Commemoration Day. The authorities added a Moment of Silence, further sanctifying the memory of those who had fallen victim to the Armenian genocide.

Strategic actors in the Armenian political leadership were initially willing to pay the price of the omission of any attribution of responsibility for the mass atrocities and the celebration of the Soviet Union as a savior of the Armenian people. Further, only pain and victimhood were on display-heroism and nationalist themes were avoided. Yet, while the memory shaped by strategic macro-level actors obviously reflects power asymmetries in Soviet Armenia, the memorial, like all elements of structural memory, is polysemic, open to reinterpretations and modifications that power holders may not be able to control (see Wagner-Pacifici and Schwartz 1991). The continuation of the story is a case in point.

\section{New Opportunities and Analogies: On Polysemy and Reinterpretations of the 1980s}

World historical changes, unfolding in the late 1980s, fundamentally affected Armenia and Armenians. They simultaneously left profound traces in Armenian collective identity and affected how Armenians remembered the events of 1915 and subsequent years. The Soviet Union became destabilized. The projects of Glasnost 
(openness) and Perestroika (restructuring), designed under Mikhail Gorbachev to save the Union, freed up sentiments in peripheral republics that had previously lain dormant. In Armenia, a flurry of interconnected events unfolded between 1988 and 1994:

- In February 1988, in mass demonstrations in the Opera Square of Yerevan, hundreds of thousands of people expressed solidarity with demands by Armenians in the Nagorno-Karabakh region. These Armenians increasingly demanded independence from Azerbaijan, to which a Soviet decision had assigned Karabakh when the Armenian Soviet Socialist Republic (SSR) separated from the Transcaucasian Republic.

- On February 20, 1988, the Soviet of People's Deputies in Nagorno-Karabakh voted to request the transfer of their region from Azerbaijan to Armenia.

- During the last days of the same month (February 27-March 1), antiArmenian pogroms took twenty-six Armenian lives (and six Azeri lives) in the Azerbaijani city of Sumgait, further fueling nationalist sentiments in Armenia. Conspiracy theories claimed that Armenians had instigated the violence to discredit Azerbaijan. Almost simultaneously, a series of mass demonstrations took place in Armenia, referred to as the Karabakh Movement. Participants in the movement demanded the incorporation of the ethnically predominantly Armenian Nagorno-Karabakh region into Armenia.

- On November 22, 1988, the legislature of the Armenian SSR passed a "Law on the Condemnation of the 1915 Genocide of Armenians in Ottoman Turkey." This law formally designated April 24 as the "Genocide Martyrs' Commemoration Day." The political leadership of the Armenian SSR had abandoned previous caution about naming the responsible country.

- Just two weeks after the passing of the law, on December 7, 1988, a horrific earthquake struck Armenia, taking between twenty-five thousand and fifty thousand lives, injuring many more, and destroying towns and villages. In response, Armenia experienced an outpouring of international aid, especially from the Armenian diaspora.

- In December 1989, the Supreme Soviets of the Armenian SSR and NagornoKarabakh passed a resolution on the formal unification of Nagorno-Karabakh with Armenia.

- New violence in Azerbaijan followed. Beginning on January 12, 1990, a sevenday pogrom unfolded against the Armenian civilian population in Baku. Ninety Armenians were killed, hundreds injured, and the majority of Armenians were expelled from the city.

- On August 23, 1990, Armenia declared its sovereignty, and the issue of the genocide was included in the Armenian Declaration of Independence: "The Republic of Armenia stands in support of the task of achieving international recognition of the 1915 Genocide in Ottoman Turkey and Western 
Armenia." The new country formally declared independence from the Soviet Union on September 21, 1991. Independence was completed on December 26, 1991.

Many of the above events motivated (or were motivated by) the NagornoKarabakh War, an ethnic and territorial conflict that started on a small scale in $1988 .^{2}$ It erupted into open warfare in early 1992, unfolding in the enclave of Nagorno-Karabakh in southwestern Azerbaijan, with ethnic Armenians, backed by Armenia, on one side and the Republic of Azerbaijan on the other. By the end of the war, in 1994, Armenians controlled almost the entire enclave and a mountain pass-originally part of Azerbaijan-that connects Armenia with Karabakh. Russia mediated, but a formal peace treaty is missing to this date. The conflict, which displaced 230,000 Armenians from Azerbaijan and 800,000 Azerbaijanis from Armenia and Karabakh, continues to linger, with occasional outbreaks of violence. Violence has again intensified into open warfare in the fall of 2020 .

Early Armenian popular mobilization, especially after the pogroms of Sumgait of February 1988, reflect an Armenian understanding of this new conflict in close affinity with the memory of 1915. Analogical bridging was at work-that is, an interpretation of current events in light of memories of the genocide. Marutyan (2007) tells us about these sentiments as he analyzes banners and posters displayed at Armenian demonstrations. He interprets them as "changing icons . . . as an index of the collective understanding of the Movement by its participants ... [and of the] stages of transformation of ethno-psychological orientations, and the changing identity of the nation as a whole" (Marutyan 2007:85).

What, then, do banners and posters tell us about shifts in collective identity and genocide knowledge at this dramatic historical juncture? Marutyan (2007) identifies several major themes, each expressed by demonstrators and captured best in titles the author chose for section headings. The first set includes "Recognize the Great Genocide of 1915"-presented in the shape of (then familiar) Soviet-style wreaths - and "We Demand of our Soviet Government that the 1915 Genocide Be Officially Recognized." This theme should not be surprising in light of the events of 1965 to 1967 , leading up to the establishment of the memorial, and the yearly anniversary commemorations ever since. Yet, at this historic moment, toleration of commemoration no longer sufficed; recognition became the demand of the day. When the government in Moscow did not respond, producers of posters directed their call to global authorities. A banner of April 1989 reads, "We appeal to United Nations to accept the Armenian Genocide."

This first episode in the unfolding drama teaches two lessons. First, the weakening of the Soviet Union provided movement leaders and Armenians generally with opportunities for the expression of nationalist agendas and associated memories, especially memories of the genocide. Second, activists seemingly hoped for a 
"boomerang effect" (Keck and Sikkink 1998). By appealing to global actors, they bargained that their country's government, not responsive to local voices, would be swayed by changing positions of a world audience.

A second set of posters established a series of causal links and analogies between different events of mass violence: "Sumgait is a sequel to the Genocide" or "Sumgait is a continuation of the Great Genocide." Other banners and posters displayed the dates "1915" (genocide) and "1988" (Sumgait pogroms) against the silhouette of Mount Ararat. They linked the current events in Sumgait, no matter the difference in scale, to the genocide of 1915 and to Armenian identity. Intensifying such analogical bridging, and thereby underlining the message, on the genocide anniversary of April 24, 1988, a khatchkar (traditional Armenian cross-stone) commemorating the victims of Sumgait was erected on the area of the genocide memorial. Other khatchkars followed in later years, commemorating subsequent pogroms.

Another poster of April 24, 1988, engages in further analogism: "Der-Zor, Buchenwald, Sumgait." This message links the Sumgait pogrom to Deir ez-Zor, a city in eastern Syria that had been a core destination of the genocidal deportations during World War I. Tens of thousands of Armenians who had survived the torturous journey perished in nearby concentration camps. Marutyan estimates the number at two hundred thousand. Buchenwald is one of the early concentration camps erected by the Nazi German government. The producers of banners thereby linked both the Armenian genocide and the Sumgait pogroms to Nazi Germany's concentration camps.

Mnemonic entrepreneurs elsewhere in the world drove the analogy between the Nazi crimes and the destruction of the Armenians further. For example, Peter Balakian wrote in The New York Times of December 5, 2008: "For Armenians, Der Zor has come to have a meaning approximate to Auschwitz. Each, in different ways, [is] an epicenter of death and a systematic process of mass killing; each a symbolic place, an epigrammatic name on a dark map. Der Zor is a term that sticks with you, or sticks on you, like a burr or thorn: 'r' ' $z$ ' 'or' —hard, sawing, knifelike.' Yet more pronounced is the statement of Armenia's president during a 2010 state visit to Syria, at the Church of Holy Martyrs at Deir ez-Zor: "Quite often historians and journalists soundly compare Deir ez Zor with Auschwitz saying that 'Deir ez Zor is the Auschwitz of the Armenians'. I think that the chronology forces us to formulate the facts in a reverse way: 'Auschwitz is the Deir ez Zor of the Jews'. Only a generation later, the humanity witnessed the Deir ez Zor of the Jews" (quoted in Marutyan 2014b:70-71). The skilled use of analogisms testifies to the narrative facility of mnemonic entrepreneurs. This strategy is especially powerful when analogical bridging links the Armenian genocide with the Shoah.

Other posters at the April 1988 demonstrations in Armenia quoted poetry of mourning from the aftermath of the 1915 genocide. Yet others, with banners reading, for example, "We demand the truth about Sumgait," called for political 
assessments of the recent pogroms and for the attribution of guilt. Some suggested appropriate answers, proclaiming that the governments of Azerbaijan and the USSR were responsible: "Moscow + Baku = Sumgait."

Increasingly, with the drive for independence intensifying, and the Soviet Union weakening further, opportunity structures became yet more favorable. Demonstrators now identified Moscow as complicit with the perpetrators. Merging the themes of Soviet guilt and Holocaust analogism, and supplementing this thematic pair with a reference to Stalinist crimes, one banner of November 18, 1988, stated: "These are our children. Buchenwald-Oswiecim-Khatin-Experience exchange-Sumgait-Masis-Zvartnots-Shushi-Stepanakert . . ." (Marutyan 2007:100). Depicted on this poster was a soldier of Nazi Germany's Wehrmacht and a Soviet internal forces soldier, shaking hands from which blood drips to the ground. Armenian movement leaders, encouraged by the lack of repressive responses by the reforming and weakening Soviet state, now began to link their memory of the genocide with the history of Soviet repression, including a repression of nationalist sentiments.

A fifth major theme, emerging in this ever-changing field of opportunities, appeared on a poster reading, "We Should Fight, Not Weep . . . " Here, the narrative moved from one of victimization to one of active, in fact forceful, agitation. Marutyan suggests:

Perhaps it was due to this, that all of about 60 posters of April 24th, 1990 completely
lacked any pleading intonations. Among the posters recorded on that day calling
for fight and for getting armed, a text taken from a fedayeen song was depicted in
six different posters ... ' 'We should fight, not weep, but fight / to gain back losses of
nation by weapons.' The fact that the text of an 80 -year-old patriotic song was so
often recalled is proof enough of a parallel between the events of the 1900 's and the
1980's, as well as of a certain resemblance in the mentality of the Armenian people
then and now. (Marutyan 2007:103)

The new Armenian identity as fighters did not replace the memory of victimization; it supplemented it, as many other posters and banners documented on the same occasion.

In short, knowledge about the Armenian genocide in Armenia proper showed both stability, due to the slow accumulation of knowledge through everyday interaction (Berger and Luckman 1966), and change. Mnemonic entrepreneurs made sure that private knowledge became public, but they also drove knowledge change. Their representational power became visible especially in the last phase of Soviet rule, when they incorporated the notion of heroism and nationalism into Armenian collective memory, built analogical bridges between genocide knowledge and repression during the Soviet (and especially the Stalinist) era, and made a further bridge to the Holocaust. Knowledge entrepreneurs initially included leaders of the national branch of the Soviet Communist Party. Later, in the 1980s, social movement leaders and their followers played crucial roles. Today, in independent 
Armenia, political leaders are prominent in this regard, in harmony with institutions such as the Museum-Institute of Tsitsernakaberd and the thousands of Armenians who make the annual pilgrimage to the genocide memorial on April 24, the anniversary of the genocide.

In the Armenian drama, as in similar situations elsewhere, some drivers of mnemonic change occupy influential institutional positions. They are highly motivated by ethno-political agendas, and they possess substantial narrative facility, skillfully using narrativization and analogisms (Rydgren 2007). All of the above factors are among the conditions Fine (2001) highlights as preconditions for successful memory entrepreneurship (see chapter 3 ). Mnemonic entrepreneurs finally recognize and seize opportunities, here the weakening and eventual breakup of the Soviet Union. While this story from Armenia entails central sociological lessons about the generation and mutation of knowledge about genocide, we gain additional analytic leverage when we examine genocide knowledge in the very different context of the Armenian diaspora.

\section{ARMENIAN GENOCIDE KNOWLEDGE IN THE DIASPORA}

Almost a century has passed since survivors of the Armenian genocide, in search of safety and new opportunities, migrated to new countries. The leading recipients were France and the United States. Here, as ethnic minorities, Armenians built up, maintained, reinforced, and defended, in mnemonic struggles, knowledge about the Armenian genocide.

Consider the United States. Today, according to U.S. Census data, 447,580 Americans self-identify as Armenian Americans, about 0.14 percent of the U.S. population. Estimates suggest, however, that the actual ethnic Armenian population is more than twice that size. Some Armenians had already arrived in the United States in the late nineteenth century, but many more followed in the context of World War I and the genocide. These populations are concentrated in California, especially in Fresno and Los Angeles, in New York, and in Massachusetts, particularly in Boston and its suburb of Watertown. Ten percent of Watertown's population are of Armenian descent.

Estimates of the size of ethnic minorities are yet more difficult in France, where the law prohibits census takers from inquiring about origin and ethnic status. Experts on French Armenian issues nevertheless suggest an ethnic Armenian population of about five hundred thousand, approximately one percent of the French people. Most French Armenians are concentrated in the metropolitan areas of Lyon, Marseille, and Paris.

In diasporic communities of both countries, communication about the mass killings was spotty in the decades immediately following the genocide, a pattern similar to that of the former Armenian SSR and its Transcaucasian predeces- 
sor. Quotations from autobiographies, interviews, and "How it was to grow up Armenian in..." reports (cited in chapter 1) provide illustrations. In regard to the United States, recall the autobiographical reflections of Peter Balakian, who would later become a Pulitzer Prize-winning writer about the Armenian genocide. Balakian had little knowledge about the genocide far into his adolescence.

In France, Serge Avédikian, a French Armenian actor and a director of powerful films with Armenian themes, and an immigrant from Soviet Armenia, observed that "in the 1970s, the Armenian community of France did not yet have all the structures it has today. One spoke rather little about the Armenians" (Avédikian and Yégavian 2017:37, translated by author). Avédikian continues: "There were not yet those claims of recognition of the genocide as organized, explicated, and written. There were not yet all those associations, and the traditional parties were very closed" (Avédikian and Yégavian 2017:37). Avédikian also writes about Armenian ghettos (ghettos arméniennes).

The rather slow development of an ethnic identity and of genocide knowledge in France may be due to several adverse conditions. Early French hostility toward the new immigrants was one factor. In 1923, for example, the mayor of Marseille referred to Armenians as "Cholera and Plague" entering the country (interview with Claire Mouradian). Armenians found themselves lower in the ethnic hierarchies than other "European" immigrant groups (on hierarchy of peoples, see Mauco 1932). Low social status challenged Armenians in everyday life all the more, as their names revealed their ethnic background (on early Armenian immigration to France, see Deschamps 1923; on "hybrid societies" and integration, see Bastide 1948). After all, Armenians had gained citizenship only after World War II. The position of Armenians in France was thus precarious far into the 1960 .

Self-identified as "guests," Armenians in France acted accordingly. They sought to contribute (e.g., serving in the military and the Résistance during World War II). After gaining citizenship, they worked to be exemplary French citizens, not to seek the benefits of the proverbial "squeaky wheel." Additional impediments for the organization of Armenian communities resulted from divisions along political lines, as well as from "snobbism" among those self-identifying as more European than newer immigrants (interview with Claire Mouradian; for details, see Mouradian and Kunth 2010). Yet the 1970s finally brought noticeable change, even against resistance. In 1975, the first major French book on the genocide appeared, and in 1973, the Armenian community of Marseille planned a genocide memorial in one of its churches. The French government, however, intervened and prevented its realization.

Commonalities in the temporal unfolding of Armenian knowledge about the genocide among immigrants to France and the United States and among Armenians in the homeland indicate that the early silence in the Soviet Union was not only a result of Soviet repression. Instead, it reflects a general tendency toward silencing found among many genocide survivors and some descendants. 


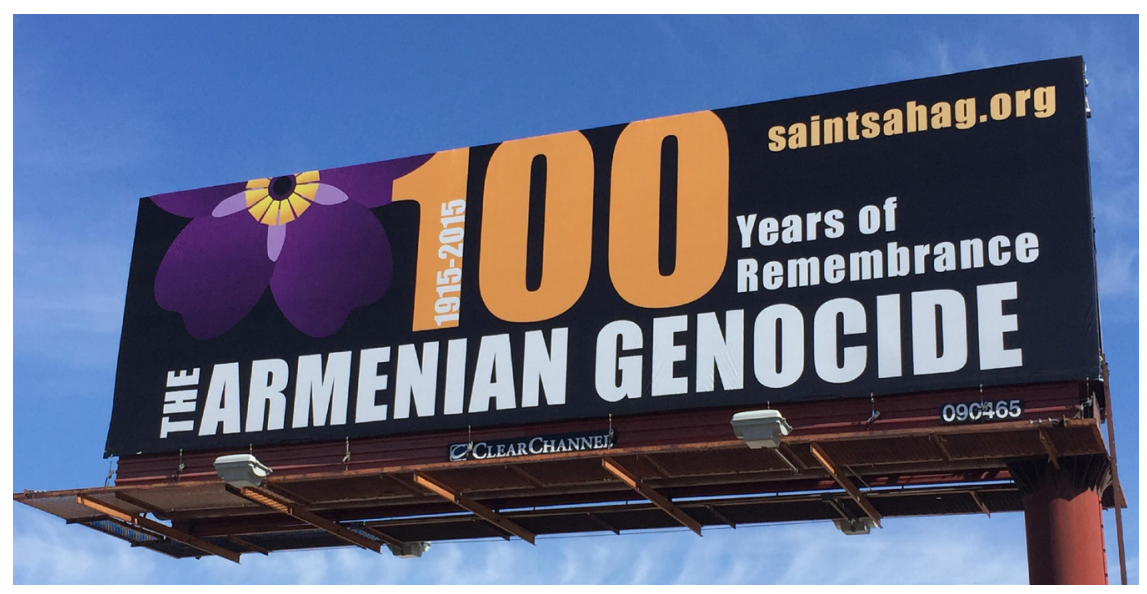

FIGURE 4. Billboard on a highway in the Twin Cities region of Minnesota, March 2015. Photo courtesy of Lou Ann Matossian.

Carol Kidron's work, cited earlier, attests to this pattern in the case of Holocaust survivors. In all of these cases, however, such silence was not to last, and France and the United States are no exceptions.

Indeed, by the end of the twentieth century and certainly by the 2015 centennial of the genocide, knowledge about the Armenian genocide was firmly entrenched in both France and the United States, in Armenian diasporic communities and in parts of the host societies. In today's America, the genocide is a regular subject of public presentations and discussions in Armenian congregations and cultural associations, whose members flock to annual April 24 commemorations. Armenian youth groups travel to the Republic of Armenia, and a visit to the genocide memorial is on their agenda as a matter of course.

On special occasions, such as the one hundredth anniversary of the genocide, Armenian organizations set up billboards along major highway arteries. In Minnesota they displayed the inscription "1915-2015-100 Years of RemembranceThe Armenian Genocide," adding "saintsahag.org," the web address of the Saint Sahag congregation that had initiated this billboard (see figure 4). Also on the one hundredth anniversary, congregations of the Armenian Church held memorial services. In the small diasporic community of Minnesota, for example, U.S. senators, representatives, and state and local officials attended and addressed those assembled in Saint Sahag Church, attesting to the representational power arising from the overlap of ethnic and religious affiliation. ${ }^{3}$

In short, emergence from marginality, strengthening of ethnic self-confidence, opportunities arising as external constraints diminish, and temporal distance from the genocide allowed mnemonic entrepreneurs to articulate forcefully the history of the Armenian genocide, and Armenians to communicate openly. The silence of early decades was broken. 
In such situations, chances of finding allies grow, and they materialized in the struggle over recognition of the Armenian genocide as well. For example, university chairs, some endowed by Armenian donors, organize symposia and lectures, as do centers for genocide studies. Academic institutions offer teacher workshops to provide high school teachers and college instructors with materials and strategies designed to evoke their students' interest in the history of Armenians, especially the genocide, a challenge in light of great geographic and historical distance. ${ }^{4}$ Initiatives intended to reach broader audiences further include teaching guidelines, issued by state departments of education (the central topic of chapter 8).

Knowledge about the Armenian genocide is as prominent in France today as it is in the United States. Armenian-French communities established a strong sense of identity in the last third of the twentieth century. They began to communicate their memory to the world around them. We will see later (in chapter 7) how these communicative efforts, paired with political strategies, were a precondition for the French legislature to pass a law in 2001 that formally recognized the Armenian genocide and a second law in 2012 that criminalized denial of the genocide-even if the latter was overruled by the Constitutional Council.

What, then, contributed to the transformation of knowledge that had remained hidden in small communities for half a century? How did it accumulate and become a publicly professed memory? Above, we have encountered mechanisms such as status gains of ethnic communities, political opportunities, ethnic and national organization, and the formation of coalitions with fields such as academia and politics. In the following sections, I elaborate on two of these mechanisms in greater depth. The first is an organization effect: the promotion of memory by ethnic organizations and their leadership. The second is a charging effect: the acquisition, by carriers of local knowledge, of universalistic academic capital and, through the latter, the extension of that knowledge into civil society.

\section{Ethnic Organizations as Carriers: An American Illustration}

Armenian ethnic organizations are potent contributors to genocide knowledge. Remember that Max Weber identified both ethnic communities and formal organizations as carrier groups. Ethnic organizations thus hold a double promise as carriers of collective memory. It becomes a triple promise, despite impediments resulting from assimilative pressure and internal tensions (Panossian 2006), when ethnicity overlaps with a specific religious identity, as is the case for substantial parts of the Armenian community. ${ }^{5}$

Recent studies by Julien Zarifian (2014) and Ben Alexander (2007) indeed highlight the central role of ethnic organizations for Armenian diasporic life and knowledge held by Armenians in the United States beginning in the early twentieth century. Local party headquarters served as social clubs for members, and each major organization published its own newspaper. Ethnic leaders play a particular 
role, as Alexander, working in the tradition of John Higham (1979), shows. They strive to build up collective identities and memory among followers, with considerable success.

The division of Armenian American organizations into two adversarial political camps, each with its own organizations, provides a natural experiment in that each set of organizations cultivated a distinct memory of Armenian history, even though both converged on the history of the genocide. On one side is the Armenian National Committee of America, earlier named the American Committee for the Independence of Armenia. Its roots are in the Armenian Revolutionary Federation (or Dashnak [also Tashnak] Party), founded in the early 189os in Tiblisi, the capital city of Georgia. The Dashnaks pursued a nationalist and socialist agenda. They dominated the first Armenian Republic (May 1918-November 1920) and strongly opposed incorporation into the Soviet Union. Accordingly, they rejected the leader of the Armenian Church in Soviet Armenia, the Catholicos at Echmiadzin, who sought to accommodate the Soviet authorities. Instead, they have recognized, since 1933, the Holy See at Antelas, Lebanon. The Dashnak side of organized Armenian life has published, since 1899 and out of Boston, a weekly newspaper, Hairenik (homeland). ${ }^{6}$

On the other side of the divide is the Armenian Assembly of America (AAA), founded in 1972. The AAA grew out of the Armenian Democratic Liberal Party, which dates back to 1921 and is rooted in the Armenakan Party of 1885 . Originally embedded in a bourgeois and clerical milieu, this party eventually broadened its base when aligning itself with the Armenian General Benevolent Union and its leader, Boghos Nubar Pasha. Motivated by political pragmatism, this strand of Armenian organizational life favored accommodation with Soviet Armenia and recognized the Catholicos at Echmiadzin. It, too, published a major newspaper to disseminate news and commentary, though the name changed repeatedly, from Azk (nation) to Baikar (struggle) after 1922, to Armenian Mirror after 1933, to AM-Spectator after 1939.

Aligned with this division between two major camps within organized Armenian American life, each side cultivated its own version of Armenian history. While the Dashnak side celebrated the 1918-20 era as one of a free and independent Armenia, often using the terms Armenian people and Dashnaks interchangeably, the AAA side depicted the era of the first Armenian Republic, under Dashnak rule, as antidemocratic, highlighting the preponderance of social problems, economic deprivation, and hunger. The division was so deep that, on December 24, 1933, a group of young Dashnaks assassinated the Armenian Archbishop of New York, Levon Tourian, during a religious service. The bishop had refused, on July 1 of the same year, to be seated under a flag of the Armenian Republic during an ethnic ceremony. Doing so would have demonstrated a rejection of Soviet Armenia and, simultaneously, of the Catholicos at Echmiadzin. The divisions between the two factions of organized Armenian life further deepened after the murder, leading to 
a formal split of the Armenian Church in America. Not surprisingly, subsequent generations of Armenian Americans would learn different accounts not only of the history of the first Armenian Republic, but also of the assassination of Archbishop Tourian. By 1933, the division and separate sets of knowledge about the first Armenian Republic were institutionalized among followers of both movements (Alexander 2007).

If ethnic leaders, through competing organizations and associated news outlets, succeeded in instilling distinct versions of Armenian state history in their followers, how much more successful must they have been in impressing on them the one issue on which both sides were in full agreement: recognition of the Armenian genocide? They succeeded indeed, and they worked to spread knowledge of the genocide to broader audiences.

The Armenian Museum of America in Watertown, Massachusetts, exemplifies both reaffirmation and outreach. Established in 1985, and affiliated with the Dashnak branch of Armenian American organizations, the museum supplements a display of Armenian material culture with an exhibit on the Armenian genocide. It features artifacts such as the clothing of a boy who was killed, bone fragments, and a Bible that belonged to a victim. Panels tell about the progression of the violence and the American response. The museum's website describes the display as a "stunning visual narrative of the events of the 1915-1923 Genocide, and the continuing aftermath and denial by the Turkish government over generations."

The establishment of the AAA and of the museum coincided, not accidentally, with an era of "ethnic revival" (Glazer and Moynihan 1970). Even if this revival is but an "ethnic myth" (Steinberg 2001), myths contribute to new cohesion among those who believe. In addition, this revival occurred during a time of intensifying Holocaust consciousness (Alexander 2002), when other victim groups were encouraged to articulate their own suffering (Novick 1999; Stein 2014). Armenian group consciousness thus solidified in this era, and Armenian organizations reached out to communicate knowledge about the genocide against their people to a broader public.

Going further, both branches of Armenian life targeted political actors. Despite different histories of political engagement, ${ }^{7}$ they have headquarters in Washington, D.C., hold regular meetings with the Armenian embassy, maintain internet sites, and network with members of Congress, especially the eighty-eight-memberstrong Armenian Congressional Caucus. ${ }^{8}$ In their fight for recognition of the genocide, they have been most successful at the state level. All U.S. states have formally recognized the Armenian genocide. At the federal level, successes include budgetary allocations to Armenia, the blocking of the nomination of a potentially hostile ambassador, and recognition of the genocide by the U.S. Congress in 2020 , during a time of heightened tensions between Turkey and the United States. As of this writing, however, no presidential administration has ever recognized the genocide; this is attributable to American political and military ties to Turkey-a 
NATO ally in the volatile Middle East_in combination with Turkey's continued staunch denial of the genocide (Zarifian 2018).

This historical account delivers a sociological lesson. Ethnic organizations function as carriers. Their leaders, as knowledge entrepreneurs, are motivated and capable of shaping the identity and consciousness of diasporic communities. Opportunities broaden in times of "ethnic revival," even of "ethnic myth." In the Armenian case, the articulation and diffusion of knowledge about the genocide is a core theme, aided by the simultaneous recognition of the Holocaust. Eventually, leaders and their followers reach beyond the in-group toward broader audiences. Their efforts are likely to succeed in a new era of human rights hegemony, a topic to which I return in chapter 9.

\section{Charging Effect: From Biography via Scholarship to French Genocide Exhibitions}

Another path toward objectivation of subjective experiences of genocide leads from biography and exposure to genocide knowledge in family or community interactions, to the world of scholarship, and on to major public statements such as the curation of a national genocide exhibit. Early motivation is charged by new currents from academic life and propelled into public view. The example of Claire Mouradian, a French scholar, illustrates this progression well. ${ }^{9}$

Born in 1951, Mouradian is a French historian, specializing in the history and geopolitics of the Caucasus, specifically Armenia and the Armenian diaspora. She is director of research at the French National Centre for Scientific Research (Centre national de la recherche scientifique, or CNRS), and she teaches at the School for Advanced Studies in the Social Sciences (École des hautes études en sciences sociales, or EHESS) in Paris.

In an interview conducted in her office at the EHESS in the summer of 2016, Mouradian told me about her grandparents, survivors of the Armenian genocide. Her grandfather was a militant (Dashnak), fighting first against the Turks and then against the Soviets. He escaped both struggles with journeys leading from his home in Diyarbekir via Istanbul, Greece, Armenia, Istanbul again, and finally to France. Mouradian also tells about her grandmother Hripsimé, originally from Sasun (Sassoun, Sason), a descendant of a "family of fighters." She reports how her grandmother found herself under a pile of corpses at age fifteen, with massive injuries, how she was taken in (or held captive) by a local Kurdish family, escaped, and eventually arrived in France. Her grandparents raised the young Claire from the age of six, after her mother died in a car accident. They lived in Paris, near Porte Saint-Martin, in the second arrondissement, rue d'Aboukir, at that time a predominantly Jewish and Armenian neighborhood. As mentioned in chapter 1, her grandmother talked with Claire about the genocide, and this transmission of knowledge and the surroundings in which Claire grew up contributed to her decision to become a historian and to specialize in Armenian history. 
An impressive career of scholarship and publishing followed. Motivation rooted in biographical experience was charged by intellectual currents, and Mouradian became an ethnic leader and mnemonic entrepreneur. In 1992, she helped reestablish the Société des Études Arméniennes, where she contributed to the publication of the (albeit short-lived, 1994-2001) scholarly journal Revue du Monde Arménienne Moderne et Contemporaine. Later she accompanied the French president when he visited Yerevan on the centennial anniversary of the genocide.

In Paris, the path from scholarship to public life is shorter than elsewhere (see chapter 7). Claire Mouradian traveled this path successfully, and in 2015, on the centennial of the genocide, she co-curated, with historians Raymond Kévorkian and Yves Ternon, a major exhibit, hosted by the Shoah Memorial (Mémorial de la Shoah) in Paris. The memorial exhibit was paralleled by a second display in the Hôtel de Ville, the city hall of Paris. Both exhibits reflect and contribute to the objectivation of knowledge about the genocide as it had developed in France by the early twenty-first century. They provide yet another opportunity to lay out the structure of sedimented knowledge of the Armenian genocide.

The full title of the exhibit at the Shoah Memorial was Le Génocide des Arméniens de l'Empire Ottoman: Stigmatiser, Détruire, Exclure (Mouradian et al. 2015). As the title suggests, it was organized in three parts. The first part, entitled "Stigmatiser" (stigmatize), provides historical background information, from early Armenian migration into Asia Minor during the times of the Trojan War; to the establishment, the waning and the waxing, and the geographic shifts of Armenia; all the way to its absorption into the Ottoman Empire. Under Ottoman rule, the viewer learns, Armenians and other minorities enjoyed limited equality and selfrule within the millet system, the partial self-administration of ethno-religious communities, but at the price of higher tax burdens and the prohibition of owning arms.

This section of the exhibit also highlights nineteenth-century military defeats of the Ottoman Empire, with substantial territorial losses in the Balkans and Caucasus. It informs the visitor that these defeats initiated a new era of stigmatization of Ottoman Armenians. Increasing repression resulted in the formation and radicalization of Armenian nationalist movements, including that of the Dashnaks. The repression turned into mass killings in 1895-96 under Sultan Abdülhamid II. Under headings such as "The Politics of the Sultan" or "The Times of Massacres," the exhibit informs the visitor that "the outcome is terrible: more than 200,000 dead, tens of thousands of orphans, mass conversions, exile of many survivors to the Russian Caucasus, Persia and the United States" (Mouradian et al. 2015:21, translated). Contemporary posters from France accompany the text tables, showing a blood-stained "Le Grand Saigneur [word play, combining Seigneur, or Master, with sang, or blood], le Sultan Abdülhamid II” (published in L'Assiette au Beurre, a French satirical magazine). Other countries stood by. An American poster, for example, shows John Bull, personification of England, looking at an Ottoman Turk 
raising his dagger and pistol against a kneeling woman, with the words "Cest difficile de les déranger-Cest un si bon client" (It is difficult to disturb them-it is such a good customer; Mouradian et al. 2015:18). Yet signs of solidarity challenge indifference. At the time of the massacres, France experienced an Armenophile mobilization, overlapping with the movement against the anti-Semitism-inspired trial of Alfred Dreyfus, and including prominent French politicians and writers such as Georges Clémenceau, Jean Jaurès, and Anatole France.

The exhibit next leads the visitor into a brief era of hope following the Young Turk revolution of 1908 (see also Der Matossian 2014). A 1908 poster, with Asia Minor in its center, shows a rainbow reaching from the western shore of the Bosporus to Armenian land in the east, with the word Constitution inserted (in the Armenian language). In addition, flags held by representatives of different ethnic groups state, each in their own language, "Autonomy," while the flags held by the Turk sport the words "Union, Equality." Yet hope was short lived. The exhibit leaves unanswered the question of whether the massacres against Armenians in the city of Adana in April 1909 should be attributed to remaining followers of the sultan or to the new Young Turk-led government. It leaves no doubt, however, that the latter responded to new territorial losses during the Balkan wars of 1912 and 1913, and the resulting flow of refugees from the Balkans to Anatolia, with a massive campaign of Turkification of space, people, and the economy.

The second part of the exhibit is entitled "Détruire" (destroy) and subtitled "La mise en oeuvre du génocide" (enacting the genocide). A large photo of the Syrian Desert, the fatal destination of hundreds of thousands of displaced Armenians, accompanies these words. This section introduces the visitor to the events of World War I as a necessary condition for the execution of the genocide. It shows how the war, and its preparation, included the advancement of nation-state ideology, support from Imperial Germany, military mobilization (also of Armenians), and military requisitions, especially directed at Ottoman Greek and Armenian businesses. Most consequential was the formation of the so-called Special Organization, a paramilitary group for combat against "tumeurs internes" (internal tumors) under the control of the party. The exhibit also points at responsible actors, detailing names and positions of the Young Turk leadership.

Moving forward in the exhibit, the visitor learns how "The Ottoman offensive on the Caucasian front is accompanied, under the cover of military operations, by localized massacres. ... Already in late March 1915, the first signs of the genocidal project can be seen: the Armenian populations of Zeytun and Dörtyol are being deported" (Mouradian et al. 2015:35, translated). ${ }^{10}$ Fifteen thousand villagers seek refuge in the city of Van from massacres committed by units of the Special Organization: "one counted 58000 victims" (Mouradian et al. 2015:35, translated). Armenian forces, concentrated in two neighborhoods, defend the city against the Turkish military for more than a month until Russian units approach. The exhibit 
reports how "these events, presented in Istanbul as an Armenian revolt, served to justify the initiation of the plan to exterminate the Armenians" (Mouradian et al. 2015:35, translated). Other elements of the exhibit show the deportation of Armenian intellectuals on April 24, 1915, a mass grave discovered by Russian troops in spring of 1916, and the deportation by train and by foot of mostly Armenian women and children to the "concentration camps" (Mouradian et al. 2015:39, translated) of Syria and Mesopotamia in the following months of 1915:

- April: 8 convoys, 35,500 deportees

- May: 21 convoys, 131,408 deportees

- June: 65 convoys, 225,408 deportees

- July: 96 convoys, 321,150 deportees

- August: 86 convoys, 276,800 deportees

- September: 5 convoys, 10,825 deportees

- October: 11 convoys, 27,500 deportees

- November: 6 convoys, 4,600 deportees

- December: 8 convoys, 7,500 deportees

Part 2 of the exhibit concludes with panels on the "Second Phase of Destruction in the Camps of Syria and Mesopotamia" (Mouradian et al. 2015:40-41). Beginning in October 1915, a department in the Ministry of the Interior set up twenty-five "concentration camps" with a capacity of eight hundred thousand. By March 1916, some "500,000 interned subsist in these camps and some other places of relegation. The Central Committee of the Young Turks now made a final decision, to move ahead with their liquidation. From April to December 1916, two locations ... were the sites of systematic massacres that caused the deaths of several hundred thousand, primarily women and children" (Mouradian et al. 2015:41, translated; see also map 1 in the introduction of this book).

Part 3 of the exhibit is entitled "Exclure" (exclude). The subtitle specifies: "Exclure du territoire, effacer de l'histoire" (Exclude from territory, erase from history; Mouradian et al. 2015:43). It addresses the small size of the remaining Armenian population in the new Republic of Turkey and the state's efforts to reduce the memory of Armenians to one of "rebels and traitors of the fatherland" (Mouradian et al. 2015:45, translated). It displays images of ruins of formerly Armenian historical sites, especially churches, and, in sharp contrast, a Turkish memorial constructed in 1997 through which Armenians are defined as genocidal killers of Turks (Mouradian et al. 2015:47). The last images of this section show "monuments against forgetting" (Mouradian et al. 2015:48-49), including a 1919 memorial erected in Constantinople (today Istanbul), but destroyed by Kemalist nationalists in 1922; the Tsitsernakaberd memorial discussed above; a memorial church and museum in Deir ez-Zor (destroyed by ISIL in 2014); and monuments in Sydney, Australia, and in Paris. The exhibit depicts these as mere examples of a wave of recognition and commemoration around the globe: 
Almost two-thirds of the seven to eight million Armenians live today in the diaspora, far from the Republic of Armenia, spread over all five continents, mostly descendants of those who escaped 1915. The chronology and geography of the memorials they erected ... allow us to trace the expansion of the diasporic space, the itineraries of exile, the processes of integration, and the status of liberty in the countries after the settlement, in private and public spaces. Virtual exhibitions in cyberspace have recently enlarged the field of expression. Each new monument constitutes simultaneously a place of gathering and a symbol in the battle against the persistent denialism in the Turkish state, which has chosen to celebrate the executioners, set to affirm the "genocide of the Turks by the Armenians." (Mouradian et al. 2015:49, translated)

In short, the exhibit examined here, hosted by the Shoah Memorial in Paris and representing the events of the Armenian genocide, displays several messages. It provides legitimization - and, in fact, celebration-of Armenian life in territories later incorporated into the Ottoman Empire. It represents Armenians as victims of mass violence. The segment on the resistance at Van, displaying Armenians as heroes, is an exception. It specifies the form of victimization (killings, death marches, starvation). It claims applicability of the genocide label, a concept that became part of international law in 1948. It also identifies responsible actors. Different from the Tsitsernakaberd site, it does not refer to "Turks" or the "Turkish State," but instead attributes responsibility more specifically to the "Young Turks," the "Committee of Union and Progress," to specific (named) actors within the government and military, and finally to military units and the Special Organization. The label "Turkish State" appears only late, primarily in the section on denialism. The specification of terms avoids a broad and generalizing attribution of guilt or responsibility. The exhibit finally points to the spread of Armenian genocide knowledge across the globe, as manifested in memorials in many countries. It does not engage in analogism, but it has been relieved of that task by its host, the Shoah Memorial in Paris. Inviting this display at the central site of French Holocaust commemoration in itself establishes a link between the Shoah and the Armenian genocide.

Importantly, the story presented here shows the process of proliferating individual, community-level knowledge. Private memory, communicated in family circles, is charged by currents from scholarship and backed by academic capital. Especially in France, such capital can be converted into political and civil-society capital to reach a broad public. Finally, the outcome of memory formation, crystallized in an exhibition, constitutes a form of structural memory, a reflection of memory in material objects. While different visitors may interpret the displays in various ways, the visual and textual representation of the Armenian genocide reflects the knowledge of Armenians as a carrier group, and it communicates it to a broad public." 


\section{CONCLUSIONS}

This chapter has examined Armenians, in the homeland and in the diaspora, as an ethno-religious carrier group of genocide knowledge. Such knowledge, however, was not the natural result of the experience of genocide. ${ }^{12}$ Over decades, widespread-even if often only partial-silencing turned to acknowledgment. History reveals the externalization and objectivation of thoughts and subjective experiences, their sedimentation as an Armenian knowledge repertoire about perpetrators, victims, and forms of victimization. It further shows both inertia and change of articulated knowledge with shifting historical contexts and ethnic organization, in the diaspora as well as in Armenia. This history finally demonstrates how entrepreneurs are at work to advance genocide knowledge within their ethnic community and to spread it toward a broad audience in their countries and globally. All of these elements, jointly, constitute the ingredients of cultural trauma.

Armenian genocide knowledge includes knowledge about Turkish reactions to and denial of the events of 1915 and subsequent years. The next chapter sets out to explicate Turkish knowledge and to show how it compares and contrasts with Armenian knowledge. 